\title{
Migrant Village Economic Development Strategy Through Tourism Development: Case study of Malang Regency of Indonesia
}

\author{
Bambang Supriadi ${ }^{1}$, and Djuwitawati Ratnaningtyas ${ }^{2^{*}}$ \\ University of Merdeka Malang ${ }^{1}$ \\ University of Merdeka Madiun ${ }^{2}$ \\ Indonesia
}

\begin{abstract}
Tourism is a source of income for developed and developing countries, especially the Indonesia-Malang Regency. This research was conducted in sub-districts that have tourism potential and are based on migrant villages. This study indicates that Malang Regency has high tourism potential but has not been widely used by rural communities. Eventually, many rural communities become migrant workers due to limited opportunities \& work opportunities, income disparities, and less productive use of income. Especially in Malang Regency, in 2016, there was an increase in the number of migrants by 21.8\%, in 2015 (1,947 migrants) and 2016 (2,490 migrants). So that a migrant village tourism development strategy is needed through the analysis as follows: Optimizing the condition of its natural potential, namely in the form of beautiful beaches and attractively packaged fish catches, to improve the quality and diversity of tourism products and increase the diversity of tourist attractions both within the attraction location. Tourism and raising the potential of natural resources that have not been developed and packaging them more attractively through tour packages, adequate facilities, homestay development, and developing cultural arts as tourism events to increase tourist attraction and face competition with similar tourist attractions.
\end{abstract}

Keywords: Strategy, Migrant Villages, Tourism.

\section{INTRODUCTION}

Malang Regency has high tourism potential but has not been widely used by rural communities. Eventually, many rural communities become migrant workers due to limited opportunities \& work opportunities, income disparities, and less productive use of income. Especially in Malang Regency in 2016, there was an increase in the number of migrants by $21.8 \%$, in 2015 (1,947 migrants) and 2016 (2,490 migrants), and Malang Regency had the most significant migrant rank in East Java province. Suppose the problem of immigrants mentioned above is not immediately found. In that case, it will impact the high number of migrants and the emergence of trafficking in person, family psychology, unprocedural migrants, and the increasing number of cases of migrant workers abroad.

Addressing the problem of migrant workers requires a solution by creating new job opportunities through Higher Education Applied Research (PTUPT) activities on Productive Migrant Village Management Models Based on Tourism Businesses to Create New Job Opportunities. The main objective of this study is to find a management model for Productive Migrant Villages based on tourism businesses to increase long-term and sustainable employment opportunities. The first research stage that has been carried out is a preliminary survey to find out social inequality in migrant villages (Limited employment opportunities and the use of unproductive income so that it triggers rural communities to work as migrants / TKI).

Analysis of Tourism Attraction Development Strategy Problems in Migrant Villages through the SWOT and EFAS-IFAS approaches. EFAS is an External Factors Analysis Summary, which is the conclusion of the analysis of various external factors that affect the sustainability of the tourism business. IFAS is the Internal Factors Analysis Summary, which is the conclusion of the analysis of various internal factors that affect the sustainability of the tourism business in Desmigratif.

Productive Migrant Villages are villages where most people work abroad, understand the system of placement and protection of workers both at home and abroad, and can build productive, independent businesses through the active role of the village government and other stakeholders [1 ]. Tourism is a variety of activities supported by various facilities and services provided by the community, business people, government, and local governments [9]. 
A tourism business is a business that provides goods and services to meet the needs of tourists and organize tourism [6]. Indonesian Workers, or called with migraines, are Indonesian citizens qualified to work abroad in the employment relationship for a certain period of pay.

\section{RESULTS \& METHODS}

Malang much has the potential of tourism in every District and village that can be fostered develop it as in the following table:

Table 1 Potential Districts Southern Region Malang Regency

\begin{tabular}{|c|c|c|c|c|}
\hline No & Districts & Name of Village & $\begin{array}{c}\text { Tourist } \\
\text { Attraction }\end{array}$ & Crafts \& Culinary \\
\hline 1 & Donomulyo & $\begin{array}{ll}\text { 1. } & \text { Tulungrejo } \\
\text { 2. } & \text { Banjarejo } \\
\text { 3. } & \text { Kedungsalam } \\
\text { 4. } & \text { Tlogosari } \\
\text { 5. } & \text { Tempursari } \\
\text { 6. } & \text { Mentaraman } \\
\text { 7. } & \text { Donomulyo } \\
\text { 8. } & \text { Purworejo } \\
\text { 9. } & \text { Sumberoto } \\
\text { 10. } & \text { Purwodadi }\end{array}$ & $\begin{array}{l}\text { Ngliyep Beach } \\
\text { Modangan Beach } \\
\text { Kondang Bandung } \\
\text { Beach } \\
\text { Bantol Beach } \\
\text { Kondang Iwak } \\
\text { Beach } \\
\text { Jonggring Saloka } \\
\text { Beach } \\
\text { Gunung Kumbang }\end{array}$ & $\begin{array}{l}\text { Crackers Samiler } \\
\text { Ginger Ginger } \\
\text { Coconut Sugar }\end{array}$ \\
\hline 2 & Bantur & $\begin{array}{ll}\text { 1. } & \text { Bandungrejo } \\
\text { 2. } & \text { Bantur } \\
\text { 3. } & \text { Karangsari } \\
\text { 4. } & \text { Pringgodani } \\
\text { 5. } & \text { Rejosari } \\
\text { 6. } & \text { Rejoyoso } \\
\text { 7. } & \text { Sumber Bening } \\
\text { 8. } & \text { Srigonco } \\
\text { 9. } & \text { Wonokerto } \\
\text { 10. } & \text { Wonorejo }\end{array}$ & $\begin{array}{l}\text { Balekambang Beach } \\
\text { Kondang Merak } \\
\text { Beach } \\
\text { Taman Ayu }\end{array}$ & $\begin{array}{l}\text { Emping Melinjo } \\
\text { Dodol Salak } \\
\text { Chipsbanana } \\
\text { MillingBatu Putih }\end{array}$ \\
\hline 3 & Gedangan & $\begin{array}{ll}\text { 1. } & \text { Gajah Rejo } \\
\text { 2. } & \text { Gedangan } \\
\text { 3. } & \text { Segaran } \\
\text { 4. } & \text { Sidodadi } \\
\text { 5. } & \text { Sindurejo } \\
\text { 6. } & \text { Sumberejo } \\
\text { 7. } & \text { Tumpakrejo } \\
\text { 8. } & \text { Girimulyo }\end{array}$ & $\begin{array}{l}\text { Bajul Mati Beach } \\
\text { Nganteb Beach } \\
\text { Wonogoro Beach } \\
\text { Jelangkung Beach } \\
\text { ungapan Beach } \\
\text { Bengkung Beach }\end{array}$ & $\begin{array}{l}\text { MonteBags } \\
\text { Pecel sauce } \\
\text { ChipsMelinjo } \\
\text { Rengginang }\end{array}$ \\
\hline 4 & $\begin{array}{l}\text { Sumbermanjing } \\
\text { Wetan }\end{array}$ & $\begin{array}{ll}\text { 1. } & \text { Argotirto } \\
\text { 2. } & \text { Druju } \\
\text { 3. } & \text { Harjokuncaran } \\
\text { 4. } & \text { Kedungbanteng } \\
\text { 5. } & \text { Klepu } \\
\text { 6. } & \text { Ringin Kembar } \\
\text { 7. } & \text { Ringinsari } \\
\text { 8. } & \text { Sekarbanyu } \\
\text { 9. } & \text { Sidoasri } \\
\text { 10. } & \text { Sitiarjo } \\
\text { 11. } & \text { Sumberagung } \\
\text { 12. } & \text { SumbermanjingWetan } \\
\text { 13. } & \text { TambakAsri } \\
\text { 14. } & \text { Tambakrejo } \\
\text { 15. } & \text { Tegalrejo }\end{array}$ & $\begin{array}{l}\text { Sendang Biru Pulau } \\
\text { Sempu } \\
\text { Butik "Andis" Sutra } \\
\text { Druju } \\
\text { Goa China Beach } \\
\text { Tamban Beach } \\
\text { Perawan Sidoasri } \\
\text { Batu Sekambing }\end{array}$ & $\begin{array}{l}\text { NecklaceSeasoning } \\
\text { BraceletSeasoning } \\
\text { Shredded Tuna } \\
\text { Banana chips Sale }\end{array}$ \\
\hline 5 & Tirtoyudo & $\begin{array}{ll}\text { 1. } & \text { Gadungsari } \\
\text { 2. } & \text { Tamankuncaran } \\
\text { 3. } & \text { Wonoagung } \\
\text { 4. } & \text { Tamansatriyan; } \\
\text { 5. } & \text { Ampelgading } \\
\text { 6. } & \text { Sukorejo; } \\
\text { 7. } & \text { Tlogosari; } \\
\text { 8. } & \text { Jogomulyan; } \\
\text { 9. } & \text { Tirtoyudo, } \\
\text { 10. } & \text { Kepatihan, } \\
\text { 11. } & \text { Sumbertangkil, }\end{array}$ & $\begin{array}{l}\text { Lenggoksono Beach } \\
\text { Bowele Beach } \\
\text { Bolu-bolu Beach } \\
\text { Banyu Anjlok Beach } \\
\text { Wedi Awu Beach } \\
\text { Sipelot Beach }\end{array}$ & Robusta \\
\hline
\end{tabular}


International Journal of Advances in Scientific Research and Engineering (ijasre), Vol 7 (9), September -2021

12. Pujiharjo.

$6 \quad$ Ampelgading

$\begin{array}{ll}\text { 1. } & \text { Argoyuwono } \\ \text { 2. } & \text { Lebakharjo } \\ \text { 3. } & \text { Mulyosari } \\ \text { 4. } & \text { Purwoharjo } \\ \text { 5. } & \text { Sidorenggo } \\ \text { 6. } & \text { Simojayan } \\ \text { 7. } & \text { Tamanasri } \\ \text { 8. } & \text { Tamansari } \\ \text { 9. } & \text { Tawangagung } \\ \text { 10. } & \text { Tirtomarto } \\ \text { 11. } & \text { Tirtomoyo } \\ \text { 12. } & \text { Wirotaman } \\ \text { 13. } & \text { Sonowangi }\end{array}$

Licin Beach Gunung Semeru Agro Kesemek Ranu Sosro
Salak Pondoh

Kopi Singo Edan

Table 2 Analysis of Migrant Village Tourism Strategy

\begin{tabular}{|c|c|}
\hline Variables & Problems \\
\hline Tourism Attractiveness & $\begin{array}{l}\text { - Decreased biodiversity of fishery resources due to the use of fishing gear that } \\
\text { is less than optimal. } \\
\text { - Lack of facilities and infrastructure as well as insight into the processing of } \\
\text { marine fishery products in } \\
\text { - the Sempu Island area which is still a conservation area. } \\
\text { - Not yet optimal management in the tourism sector, especially in the Sempu } \\
\text { Island area. }\end{array}$ \\
\hline Accessibility & $\begin{array}{l}\text { - There is no public transportation that reaches the Village } \\
\text { - Narrow and damaged roads hinder accessibility. }\end{array}$ \\
\hline Variable & Problems with \\
\hline Tourism Facilities & $\begin{array}{l}\text { - Limited number of public toilets } \\
\text { - Inadequate parking space }\end{array}$ \\
\hline $\begin{array}{l}\text { Village facilities and } \\
\text { infrastructure }\end{array}$ & $\begin{array}{l}\text { - Waste management in settlements is still partially disposed of or burned so } \\
\text { that it disturbs environmental cleanliness }\end{array}$ \\
\hline & $\begin{array}{l}\text { - Only one telecommunications provider is able to reach Tambakrejo village, } \\
\text { thus hampering visitor/tourist communication }\end{array}$ \\
\hline Human resources & $\begin{array}{l}\text { - Level education is still low The } \\
\text { - Quality of the workforce in the tourismstill low }\end{array}$ \\
\hline Information and Promotion & $\begin{array}{l}\text { - Sector isThere is no management related to tourism Tourism } \\
\text { - Service activities run naturally played by individuals. }\end{array}$ \\
\hline
\end{tabular}

\subsection{SWOT and EFAS-IFAS}

Based on the IFAS and EFAS assessments, it can be seen that the position of the SWOT quadrant for Potential Development of Migrant Villages as a Tourism Village is in quadrant I Room B, namely Stable Growth Strategy, meaning that the strategy for stable growth and development is carried out in stages. The target is adjusted to current conditions. This is a favorable situation because it has considerable opportunities and strengths to achieve the tourism village development desired by the community. 


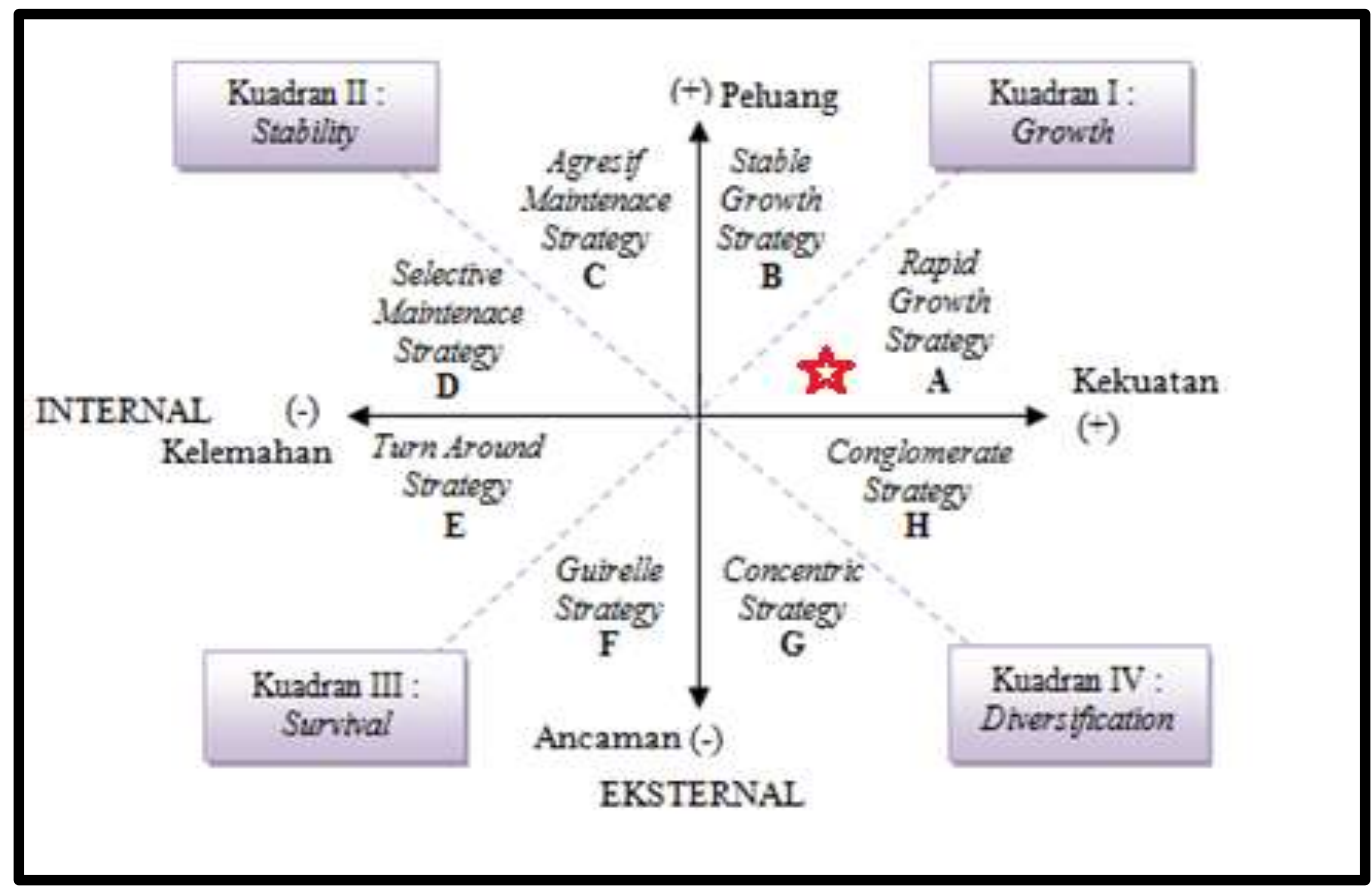

Figure 1 Position of the Migrant Village Development Strategy Quadrant The development

\subsection{Strategy includes:}

a. Optimizing the condition of the natural potential possessed, namely in beautiful beaches and attractively packaged fish catches, improves the quality and diversity of tourism products [24].

b. Increasing the diversity of tourist attractions both within tourist attraction locations as well as raising the potential of natural resources that have not been developed and packaging them more attractively through tour packages, adequate facilities, and homestay development as well as developing cultural arts as events tourism to increase tourist attraction and face competition with similar tourist attractions [25]

c. Optimizing the role of management in developing equal potential in each hamlet and continuing development programs such as socialization, training, and capital assistance with more frequent and even intensity for the development of homestays and improving the quality of human resources.

d. Improve service through the provision of facilities, infrastructure, and accessibility of adequate supported policies Malang regency related to the development of tourism in order to support the needs and comfort of tourists

e. We utilize local labor availability and optimize community participation supported by local government policy to develop a tourist attraction and boost the local economy.

f. There is a need for integrated waste management in Migrant Villages, especially in each tourist attraction.

Strategies in stabilization programs amenities(amenities)and spur increased support facilities(ancillary service)travel to provide travel services through the analysis of supply and demand in the migrant village, then the first mapping of the potential of tourism in the 6th District of the southern region based on the migrant village.

\subsection{Description of Tourist Attractions Tourist}

Attractions in Migrant Villages, Malang Regency, are divided into natural and cultural resources. These tourist attractions include: The natural beauty, of Migrant Village is a coastal village in the southern part of Malang Regency, which has a landscape of beaches and hills. So that makes this Migrant Village has a dazzling natural beauty and is used as an attraction. Sendiki Beach, is one of the beaches in the Migrant Village that is unspoiled, has cool air, has a relatively long stretch of white sand and high waves. Unfortunately, the beach's location is a bit hidden behind a hill, so to get there, you have to walk for $1 \mathrm{~km}$, and the vehicle only arrives at the parking lot. Tamban Beach Tamban,

Beach has white and clean sand along approximately $1.5 \mathrm{~km}$, the beach is excellent, and the waves are pretty calm because it is directly opposite Sempu Island. However, Tamban Beach is a bit empty of visitors compared to Sengki Beach; only a few visitors enjoy Tamban Beach and enjoy lunch at one of the grilled fish stalls. Sendang Biru Beach, Sendang Biru Beach is one of the tourist areas owned by Perum Perhutani and managed by Unit II. Sendang Biru has an exciting view: clean white sand, clear seawater, and colorful fishing boats leaning neatly on the beach. This beach is directly opposite Sempu Island, separated by the 
narrow Sempu Strait and 4 kilometers long. The attraction of this beach is the fish market at the fish auction place (TPI) and diesel engine boat tours around the coast.

Teluk Asmara, Beach Teluk Asmoro Beach is a lovely and natural beach; several islands adorn this beach. As the name suggests, this beach forms a small bay with relatively calm waves and has quite clear seawater, coral reefs and rocks are visible, and beautiful small fish are roaming around. Teluk Asmara Beach is often referred to as the miniature of Raja Ampat. Sempu Island, Sempu Island has an alluring attraction, namely the Segara Anakan Lagoon, a beach on the island with a stretch of white sand and 4 ha. However, the tourist area of Sempu Island is predominantly overgrown by tropical trees covering an area of 877 ha; this is a nature reserve that is directly managed by the East Java Natural Resources Conservation Center (BBKSDA) and the Ministry of Forestry. Fishery products, The fishery sector is the primary sector in Migrant Villages; fish products are pretty abundant every year.

The fish products consist of tuna, tuna/skipjack, snapper, squid, and sardines. The fishery sector in the Migrant Village is also supported by adequate facilities, namely a fish market and TPI. The picking ceremony, Local wisdom in Migrant Village is a "Sea Picking" ceremony; this ceremony is a traditional ceremony held every year on September 27. During the "Petik Laut" activity, there are several sub-activities: a series of the "Petik Laut" ceremony procession; these activities are packaged into events conditional with cultural and religious nuances. This ceremony is held on the coast of Sendang Biru Beach and is preserved by the local community.

Table .3 Directions for Development of Tourism Attractions in Migrant Villages

\begin{tabular}{|c|c|}
\hline $\begin{array}{c}\text { Tourist } \\
\text { Attractions }\end{array}$ & Analysis \\
\hline \multirow[t]{3}{*}{$\begin{array}{l}\text { Something to } \\
\text { Do }\end{array}$} & $\begin{array}{l}\text { Camping is an activity that can be done by tourists who have a love for nature. Sendiki Beach } \\
\text { and Sempu Island are available for tents. }\end{array}$ \\
\hline & $\begin{array}{l}\text { This area can be researched, especially those related to the socio-cultural community as well as } \\
\text { those related to the environment. }\end{array}$ \\
\hline & $\begin{array}{l}\text { Visitors who like photography can take advantage of the natural conditions in the form of flower } \\
\text { gardens or others in this village. }\end{array}$ \\
\hline
\end{tabular}

Something High and beautiful waves can only be found at Sendiki Beach. The colorful beauty of to See fishing boats can be found at Sendangbiru Beach and Tamban Beach

. Beautiful natural scenery can be enjoyed in all attractions, each of which has its own uniqueness.

Fishermen's settlements can be found at Tamban Beach and Sendangbiru Beach, while other attractions are located far from settlements.

The sea picking ceremony which is held every September 27 can be enjoyed at Sendangbiru Beach.

Something Grilled fish is a typical food from Migrant Villages. Tourists who can buy souvenirs in the form of to Buy grilled fish are sold in several stalls. However, the grilled fish is only found in Tamban Beach, Sendiki and Sendang Biru

Fresh fish of good quality can be obtained in Migrant Villages. Tourists who come can also bring home in the form of fresh fish that can be obtained at Sendang Biru and Tamban Beach.

Something Sendiki Beach is unique in the form of fairly large waves, white sand, and unique play facilities to See (swings and wooden houses on

Tamban Beach are unique in the form of fishing boats on the shoreline and food stalls that offer a place to eat overlooking the beach). to the beach.

Blue Spring beach has a unique, scenery of fishing boats were great and the colors are leaning on the shoreline, the diversity of fresh fish, the TPI and the fish market

Gulf Coast Asmara is a beach that is still relatively new, and recently opened by local residents. This beach also has its own uniqueness, namely it has small islands, often referred to as the miniature of Raja Ampat in Papua

. Sempu Island is a conservation area and its own beauty; immediately saplings 


\subsection{Facilities And Infrastructure}

Accommodation (hotel/lodging) Hotel / Lodging in Migrant Village consists of, homestay, guesthouse, and treehouse. On Sendiki Beach has a unique inn, namely in the form of a treehouse. The price per night is Rp. 150,000. Places to eat and drink/stalls. In the Migrant Village, there are several stalls selling food, especially grilled fish stalls typical of the Migrant area. These stalls are located in each tourist attraction; only Sempu Island and Teluk Asmara are unavailable for food stalls.

Parking is one of the supporting facilities for tourism which is no less critical than other facilities. Each tourist attraction has adequate parking space. It is just that some parking lots do not have parking attendants, such as at Tamban Beach and Teluk Asmara, so they look untidy.

$\mathrm{MCK} /$ public toilets are essential infrastructure facilities to support tourism activities. Currently, there are MCK/public toilets at Tamban Beach, Sendiki, and Sendang Biru, while at Teluk Asmara Beach, it is still under construction. Places of worship in this Migrant Village have mosques and churches; the number of churches is more than mosques because most Migrant Village residents are Christians. In addition, there are several mosques and churches located in residential areas, and there are also prayer rooms at Tamban Beach and Sendiki Beach.

Security Post, the Migrant Village has several security posts, including in settlements, at Tamban Beach and Sendiki Beach. Cleanliness. Until now, cleanliness in the Migrant Village has been experiencing problems. Residents are starting to get overwhelmed in handling waste from visitors, especially plastic waste; residents want to process it but still do not know how to process it.

\subsection{Accessibility}

Access to the tourism village can be pretty good; the road is already asphalt with sufficient width. It is just that you have to go through the hills, so the road is winding. To be precise, several roads are still dirt roads, the road to Sendiki Beach and Teluk Asmara. The journey from Malang City to Migrant Village is 3 hours away if there are no problems. It is just that there is no public transportation to get there, so you have to use a vehicle. Visitors' impressions of tourists state that there is still a need for repair and rearrangement; most visitors are very impressed and want to come back another time and are impressed by the natural beauty and culture.

Table 4 Problems in Tambakrejo Migrant Village

\begin{tabular}{lll}
\hline \multicolumn{1}{c}{ Variables of } & & \multicolumn{1}{c}{ Potential of Tourism } \\
\hline Tourist & $\bullet$ & Tambakrejo village has 6 (six) tourist attractions that have their own uniqueness, namely \\
Attractions & Sendiki Beach, Tamban Beach, Sendang Biru Beach, Teluk Asmara Beach and Sempu \\
& Island, as well as sea picking ceremonies. \\
Accessibility The & $\bullet$ & The productivity of marine fish is quite abundant, with various types. \\
& $\bullet$ & Most of the roads in Tambakrejo Village are asphalt, only a few sections are still plaster \\
& and dirt roads. \\
& The location of Tambakrejo village is easily accessible by
\end{tabular}

\subsection{Tourists}

Based on the questionnaire distributed to visitors in the Migrant Village at random, it totals 100 respondents. It can be seen that most of the visitors who visit the Migrant Village are aged 26-35 years.

Variables

\section{Potential of Tourism}


- Village youths who rarely migrate, they are more likely to return and build their villages.

Information and - The beauty of several attractions in Tambakrejo Village has been known by the Promotion general public through the internet and tourism brochures in Malang Regency.

\section{CONCLUSION}

The migrant village tourism development strategy through the analysis is as follows : Optimizing the conditions of its natural potential, namely in the form of beautiful beaches and attractively packaged fish catches, to improve the quality and diversity of tourism products and increase the diversity of tourist attractions both within the attraction location tourism as well as raising the potential of natural resources that have not been developed and packaging them more attractively through tour packages, adequate facilities and homestay development as well as developing cultural arts as events tourism to increase tourist attraction and face competition with similar tourist attractions.

Optimizing the role of management in developing potential evenly distributed in each hamlet and continuing development programs such as socialization, training, and capital assistance with more frequent and even intensity for the development of financial homestays and improving the quality of human resources. improve services through the provision of adequate facilities, infrastructure, and accessibility supported by Malang Regency policies related to tourism development in order to support the needs and comfort of tourists

We are utilizing the availability of local labor and optimizing community participation supported by local government policies in developing tourist attractions and improving the local economy and The need for integrated waste management in Migrant Villages, especially in each tourist attraction.

\section{REFERENCES}

[1] Ministry of Manpower and Transmigration, 2017 Desmigration Program Guidelines.

[2] G. Prayitno, A. A. Nugraha, N. Sari, and P. U. Y. Balqis, "The Impact of International Migrant Workers on Rural Labor Availability (Case Study of Ganjaran Village, Malang Regency),” Procedia Environ. Sci., vol. 17, pp. 992-998, 2013.

[3] Central Bureau of Statistics, Malang Regency in Figures 2017, vol. 17. 2017.

[4] H. Janta, L. Brown, P. Lugosi, and A. Ladkin, "Migrant relationships and tourism employment," Ann. Tours. Res., vol. 38, no. 4, pp. 1322-1343, 2011.

[5] M. M. Astro, "Malang Regency Government Prepares Two Productive Migrant Villages," 2017. [Online]. Available: http://www.radiokanjuruhanfm.com/berita-area/805-pemkab-malang-prepare-dua-desa-migran-produktif.html.

[6] Kemenparekraf, PP No. 50/2011-National Tourism Development Master Plan 2010-2025, no. 2003. Jakarta, 2011.

[7] K. Research and D. A. N. P. Tinggi, “National Research Master Plan 2017-2045,” vol. 2045, pp. 1-110, 2017.

[8] LPPM, Resntra Merdeka University Malang 2016-2021. Malang, 2016.

[9] Republic of Indonesia, Law of the Republic of Indonesia Number 10 of 2009 concerning Tourism. Indonesia: Indonesia, 2009, pp. 1-34.

[10] B. Anderson, "Migration, immigration controls and the fashioning of precarious workers," Work. Employ. Soc., vol. 24, no. 2, pp. 300-317, 2010.

[11] S. W. Latifah, "NETWORKING ADVOCACY STRATEGIES FOR INDONESIAN WORKERS BY THE INDONESIAN MIGRANT WORKERS UNION (SBMI) MALANG,” J. Government Science, vol. 6, no. 1, pp. 1-20, 2014

[12] A. Afrindo, "Networked Advocacy Strategy for Indonesian Migrant Workers by the Indonesian Migrant Workers Union (Sbmi) Malang,” J. Government Science. Univ. Brawijaya Malang, vol. 7, no. 13, pp. 1-21, 2014.

[13] C. Giambi, M. Del Manso, T. Dalla Zuanna, F. Riccardo, A. Bella, MG Caporali, A. Baka, N. Caks-Jager, T. Melillo, R. Mexia, G. Petrović, and S. Declich, "National immunization strategies targeting migrants in six European countries," Vaccine, 2018. 
[14] P. Milbourne and L. Kitchen, "Rural mobility: Connecting movement and fixity in rural places," J. Rural Stud., vol. 34, pp. 326-336, 2014.

[15] M. Nafi, B. Supriadi, and N. Roedjinandari, "Internal Marketing Impact On External Service Quality In Semeru Pine Forest ( Spf ) Tourist Attraction,” IOSR J. Bus. Manag., vol. 20, no. 7, pp. 66-72, 2018.

[16] A. Ladkin, “Exploring tourism labor,” Ann. Tours. Res., vol. 38, no. 3, pp. 1135-1155, 2011.

[17] B. Supriadi and N. Roedjinanndari, Planning and Development of Tourism Destinations, First. Malang: Malang State University Printing, 2017.

[18] R. Jack, Eastern European migrant workers and the Scottish tourism industry: The economic impact, no. 84. 2007.

[19] C. M. Rogerson, "Informal Sector Business Tourism and Pro-poor Tourism: Africa's Migrant Entrepreneurs," Mediterr. J. Soc. Sci., vol. 5, no. 16, pp. 153-161, 2014.

[20] C. Aitken and C. M. Hall, "Migrants and foreign skills and their relevance to the tourism industry," Tour. Geogr., vol. 2, no. 1 , pp. 66-86, 2010.

[21] M. Joppe, "Migrant workers: Challenges and opportunities in addressing tourism labor shortages," Tour. Manag., vol. 33, no. 3, pp. 662-671, 2012.

[22] The Word Economic Forum, The Travel \& Tourism Competitiveness Report 2017. Geneva: The Word Economic Forum, 2017.

[23] H. A. Imran, "The Role of Sampling and Data Distribution in Communication Research Quantitative Approach," Stud. commune. Dan Media, vol. 21, pp. 111-126, 2017.

[24] Sandrio, L., Hidayatullah, S., Supriadi, B., \& Patalo, R.G. (2020). Effect Of Tourism Satisfaction As A Mediator Variable Of Images Of Destination And Facilities To Loyalties On Millenial Generation To Visit Bromo Tengger Semeru. International Journal of Scientific \& Technology Research, 9, 183-187.

[25] Nafi, M. and Supriadi B., (2017), 'Strategies of Tourism. Development through cotourism Spectrum for Increasing Tourists' Visit', in Rural Resarch and Palanning Group and Palanning Group, pp. 75-85. 